\title{
Application of Agarose Gel Electrophoresis to the Characterization of Plasmid DNA in Drug-resistant Enterobacteria
}

\author{
By GERALDINE A. WILLSHAW, H. R. SMITH \\ AND E. S. ANDERSON* \\ Enteric Reference Laboratory, Public Health Laboratory Service, \\ Colindale Avenue, London NW9 5 HT
}

(Received 21 November 1978; revised 16 February 1979)

\begin{abstract}
A simple gel electrophoresis method has been described for the detection of plasmid DNA in bacteria (Meyers et al., 1976). We investigated further the problems encountered in using this method for the analysis of plasmids in wild enterobacterial strains. The migration of open circular and linear plasmid DNA was examined, since these forms sometimes caused difficulty in the interpretation of the plasmid content of uncharacterized strains. Electrophoresis at different agarose concentrations was employed to resolve clearly plasmid DNA from the chromosomal DNA fragments in the crude preparations. Dissociation of some plasmids occurs in Salmonella typhimurium, and this was detected by electrophoresis.

The technique was applied to the study of drug-resistant strains of $S$. typhimurium phage type 208 from several Middle Eastern countries. The cultures carry a drug resistance plasmid of the $\mathrm{F}_{\mathrm{I}} m e$ compatibility group, and at least two other plasmids which were detected and identified by gel electrophoresis. The studies supported and extended the genetic findings and provided information on the distribution of particular plasmids.
\end{abstract}

\section{INTRODUCTION}

Epidemiological studies of pathogenic bacteria require techniques for the identification and characterization of different strains. Important properties, for example drug resistance, are frequently coded for by plasmids and these can be studied by several different methods. Genetic analysis, such as compatibility grouping, has been widely used to classify bacterial plasmids. Similarities or differences between plasmids identified in different strains may also be detected by molecular characterization including DNA reassociation studies.

Recently, the technique of agarose gel electrophoresis has been applied to the study of covalently closed circular (CCC) plasmid DNA (Meyers et al., 1976). The method is rapid, relatively inexpensive and technically simple and is suitable for the examination of a large number of bacterial cultures. The plasmid content of several bacterial species has been examined by this method (Meyers et al., 1976; Crosa et al., 1977). However, there are limitations in the application of this technique in epidemiological studies in which it is important to determine unambiguously the number and sizes of plasmids in different wild strains. Such strains frequently carry up to five or six plasmids of different types and sizes. We have investigated the conditions for gel electrophoresis in an attempt to extend its use in the analysis of wild strains. In particular, we have studied the interference of chromosomal DNA fragments and of multiple plasmid DNA forms in the detection and identification of plasmids.

We have examined some drug-resistant strains of Salmonella typhimurium which originated in several Middle Eastern countries. The cultures all carry resistance plasmids of the $F_{1} m e$

* Present address: 10 Rosecroft Avenue, London NW3 7QB.

0022-1287/79/0000-8469 \$02.00 (C) 1979 SGM 
Table 1. Standard plasmids

\begin{tabular}{|c|c|c|c|}
\hline Plasmid* & $\begin{array}{l}\text { Drug resistance } \dagger \\
\text { or other markers }\end{array}$ & $\begin{array}{c}10^{-6} \times \\
\text { Molecular } \\
\text { weight: }\end{array}$ & Reference \\
\hline ColE1 & colicin E1 & $4 \cdot 7$ & Fredericq (1956) \\
\hline NTP16 & AK & $5 \cdot 7$ & Anderson et al. (1977) \\
\hline NTP7 & ASSu & $9 \cdot 4$ & Smith et al. (1974) \\
\hline NTP14 & $\begin{array}{l}\text { A, colicin E1, EcoRI } \\
\text { restriction and } \\
\text { modification enzymes }\end{array}$ & $11 \cdot 4$ & Smith et al. (1976) \\
\hline NTP106 & $\mathrm{K}$ & $14 \cdot 5$ & This laboratory \\
\hline & $\mathrm{AKT}$ & $37 \cdot 8$ & Datta et al. (1971) \\
\hline $1-19 K^{-}$ & $\mathrm{ACSSu}$ & $54 \cdot 2$ & Meynell \& Cooke (1969) \\
\hline
\end{tabular}

* Plasmids with the prefix NTP are non-autotransferring.

$\dagger$ Symbols for drug resistances: A, ampicillin; C, chloramphenicol; K, kanamycin; S, streptomycin; Su, sulphonamides; $\mathrm{T}$, tetracyclines.

\$ Molecular weight determined by electron microscopy in this laboratory.

compatibility group (Threlfall et al., 1976; Anderson et al., 1977) and other plasmids coding for drug resistance. The plasmids present in these strains have been detected on gels and the number and sizes of plasmids present in cultures from the different countries have been compared. A preliminary account of these investigations has been published (Willshaw et al., 1977).

\section{METHODS}

Bacterial strains and plasmids. Table 1 lists the standard plasmids employed in this investigation, their relevant genetic markers, including drug resistance, and their molecular weights as determined by electron microscopy. The sizes of plasmids used in molecular weight determinations are listed in the legends to the figures.

For the preparation of plasmid DNA, the plasmids concerned were usually introduced into standard carrier strains. These were Escherichia coli $\mathrm{K} 12^{-\mathrm{F}^{-}}(=\mathrm{K} 12)$ or its nalidixic acid-resistant derivative, and a line of $S$. typhimurium phage type 36, which has lost the plasmid MP10 (Smith et al., 1973). The recipient strain for transformation experiments was $E$. coli $\mathrm{K} 12 \mathrm{C} 600$. The origin and properties of the wild $S$. typhimurium strains from which plasmid DNA was prepared are given in Table 2.

Isolation of partially purified plasmid DNA. Plasmid-carrying strains of E. coli $\mathrm{K} 12$, S. typhimurium type 36 or wild $S$. typhimurium were grown in 50 to $200 \mathrm{ml}$ nutrient broth. Bacteria were usually lysed with a mixture of Brij 58 and sodium deoxycholate (Clewell \& Helinski, 1969); lysis with sodium dodecyl sulphate (Guerry et al., 1973) was sometimes employed for $S$. typhimurium cultures. The procedure of Meyers et al. (1976) was the basis for the subsequent partial purification of plasmid DNA.

Preparation of pure plasmid DNA. Radioactively labelled plasmid DNA for electron microscopy was prepared as described by Willshaw et al. (1978). Large quantities of pure plasmid DNA for electrophoresis were obtained from cleared lysates of plasmid-carrying strains; plasmid DNA was precipitated with polyethylene glycol 6000 and purified by caesium chloride-ethidium bromide dye-buoyant density gradient centrifugation (Humphreys et al., 1975).

Agarose gel electrophoresis of plasmid DNA. Electrophoresis was performed in vertical slab gels $(16 \times$ $15 \times 0.4 \mathrm{~cm}$ ) which usually contained $0.75 \%(\mathrm{w} / \mathrm{v})$ agarose (BDH electrophoresis grade). Some plasmid DNA preparations were analysed at several agarose concentrations, as indicated in the text. The electrophoresis buffer, pH 8 to $8 \cdot 2$, contained $89 \mathrm{~mm}$-Tris, $2.5 \mathrm{~mm}$-EDTA and $89 \mathrm{~mm}$-boric acid (Greene et al., 1974).

Crude ethanol-precipitated DNA ( 2 to $100 \mu \mathrm{l}$ ) or pure plasmid DNA was mixed with a solution of $60 \%$ $(\mathrm{w} / \mathrm{v})$ sucrose and $0.25 \%(\mathrm{w} / \mathrm{v})$ bromophenol blue in $0.03 \mathrm{M}-\mathrm{Tris} / \mathrm{HCl} \mathrm{pH} 8.0$ containing $0.05 \mathrm{M}-\mathrm{NaCl}$ and 0.005 м-EDTA. Samples loaded on to gels contained 6 to $10 \%(\mathrm{w} / \mathrm{v})$ sucrose. Electrophoresis was at a constant voltage of $140 \mathrm{~V}$, a voltage gradient of $8.7 \mathrm{~V} \mathrm{~cm}^{-1}$, for 2.5 to $4 \mathrm{~h}$ at room temperature. Gels were soaked for $30 \mathrm{~min}$ in a solution of ethidium bromide $\left(0.5 \mu \mathrm{g} \mathrm{ml}^{-1}\right.$, in water) and viewed under long and short wavelength ultraviolet light (Chromatovue cabinet, Ultra Violet Products). DNA bands were photographed on Polaroid type 52 Land film or Kodak Tri-X, using a $\times 7$ red filter.

Electron microscopy of plasmid DNA. Techniques for the examination of plasmid DNA have been described 
(a) $0.75 \%$ agarose

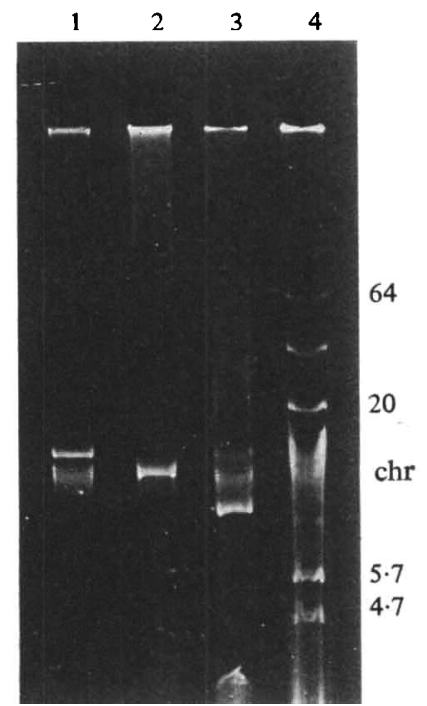

(b) $0.65 \%$ agarose

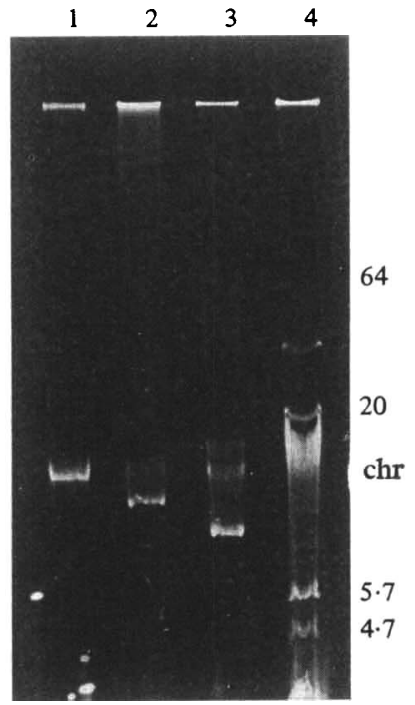

(c) $1.0 \%$ agarose

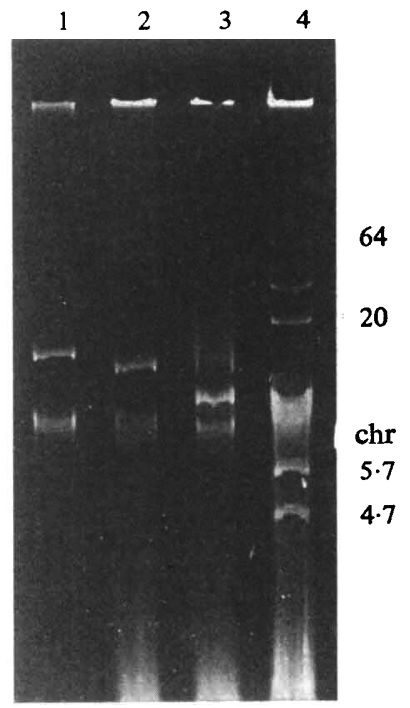

Fig. 1. Separation of plasmid and chromosomal DNA at different agarose concentrations. Partially purified preparations were subjected to electrophoresis for 3.5 to $4 \mathrm{~h}$ at room temperature. The same preparations were run in tracks 1 to 4 at agarose concentrations of $(a) 0.75 \%,(b) 0.65 \%$ and $(c)$

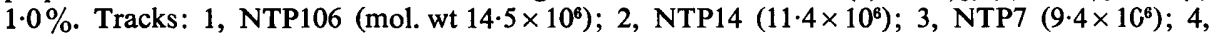
standard plasmids of molecular weights $\left(\right.$ all $\left.\times 10^{6}\right) 4 \cdot 7,5 \cdot 7,20 \cdot 2,31 \cdot 7,64 \cdot 0$. Abbreviation: chr, chromosomal DNA fragments.

previously (Grindley et al., 1973). The contour length of plasmid DNA was determined and molecular weights were calculated on the assumption that $1 \mu \mathrm{m}$ is equivalent to a molecular weight of $2.07 \times 10^{6}$ (Lang, 1970).

Transformation of E. coli K12. Partially purified preparations containing plasmid DNA were dialysed for about $36 \mathrm{~h}$ against two changes of $75 \mathrm{~mm}$-calcium chloride. Transformation of $\mathrm{CaCl}_{2}$-treated cells of E. coli K12 C600 was performed by the method of Cosloy \& Oishi (1973) as modified by Humphreys et al. (1979).

\section{RESULTS AND DISCUSSION}

\section{Separation of plasmid and chromosomal DNA}

Partially purified plasmid DNA obtained by ethanol precipitation of phenol-treated cleared lysates contained plasmid DNA molecules which migrated on agarose gels generally as single bands at a rate inversely related to their molecular weights (Meyers et al., 1976). The preparations also contained varying amounts of fragmented chromosomal DNA not removed in the preparation of cleared lysates of plasmid-carrying strains, and this banded as a broad diffuse area (see Fig. 1). The brightness and size of this region might obscure plasmid DNA bands over a significant range of molecular size and therefore interfere with the detection of plasmids in uncharacterized strains. We examined the separation of plasmid and chromosomal DNA bands using plasmids of molecular weight $9 \times 10^{6}$ to $15 \times 10^{6}$ which were partially purified from $E$. coli $\mathrm{K} 12$. They were subjected to electrophoresis on gels of different agarose concentration in order to alter the mobility of the plasmids relative to that of the linear chromosomal DNA fragments. It has been shown that the separation of the linear and CCC forms of the same plasmid DNA is highly dependent on gel strength (Johnson \& Grossman, 1977).

Figure 1 (a) shows migration of NTP7 (mol. wt $\left.9 \cdot 4 \times 10^{6}\right)$, NTP14 $\left(11 \cdot 4 \times 10^{6}\right)$ and NTP106 $\left(14.5 \times 10^{6}\right)$ on $0.75 \%$ agarose. NTP14 appeared as a band running within the chromosomal DNA region (track 2) and NTP106 and NTP14 were just separated from this region (tracks 1 and 3 ). On $0.65 \%$ agarose (Fig. $1 b$ ), the mobility of CCC DNA molecules was increased 


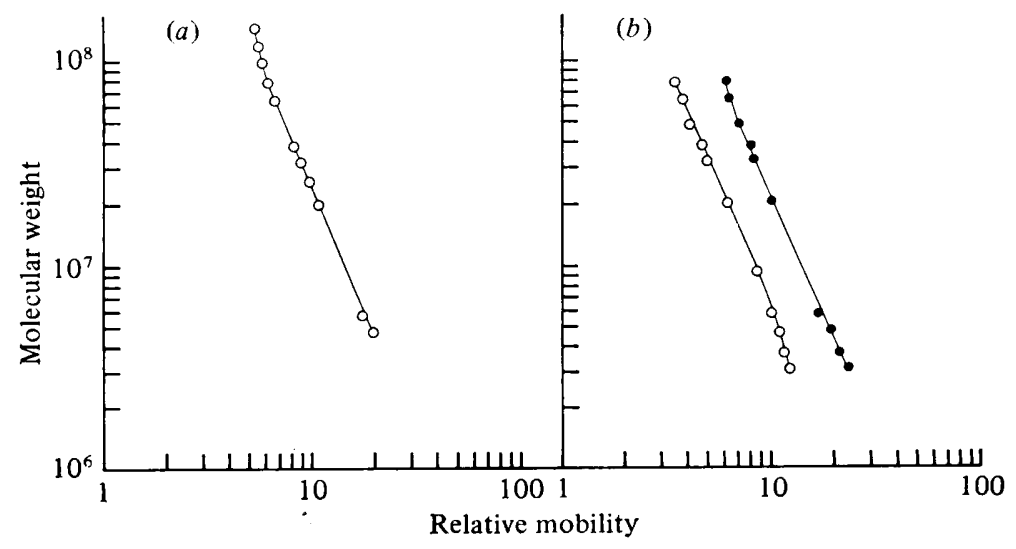

Fig. 2. Determination of molecular weights of plasmid DNA by agarose gel electrophoresis. The logarithmic plots show molecular weight as a function of relative mobility for plasmid DNA of known size, partially purified from $E$. coli $\mathrm{K} 12$. (a) $0.75 \%$ agarose, taking the mobility of the plasmid $\mathrm{Sa}\left(25 \cdot 9 \times 10^{6}\right)$ as 10 . Sizes of other plasmids $\left(\right.$ all $\left.\times 10^{6}\right): 4 \cdot 7,5 \cdot 7,20 \cdot 2,31 \cdot 7,37 \cdot 8,64 \cdot 0,77 \cdot 6$, $100,123,144$. (b) $0.65 \%$ agarose $(O)$, taking the mobility of $5.7 \times 10^{8}$ plasmid as 10 , and $1.0 \%$ agarose $(0)$, taking the mobility of $20 \cdot 2 \times 10^{6}$ plasmid as 10 . Sizes of other plasmids (all $\times 10^{6}$ ): $3 \cdot 1,3 \cdot 7,4 \cdot 7,5 \cdot 7,9 \cdot 4,20 \cdot 2,31 \cdot 7,37 \cdot 8,48 \cdot 0,64 \cdot 0,77 \cdot 6$.

relative to that of chromosomal DNA fragments, which extended over a position corresponding to $12 \times 10^{6}$ to $17 \times 10^{6}$. The plasmid NTP7 was therefore clearly resolved ahead of the chromosome (track 3) while NTP106 migrated within the chromosomal region (track 1). By electrophoresis on 1\% agarose, both NTP106 and NTP14 could be separated from chromosomal fragments (Fig. $1 c$, tracks 1 and 2), whereas on this gel NTP7 migrated just behind the chromosomal region (track 3 ).

Analysis of plasmid DNA preparations from wild and other strains was initially performed on $0.75 \%$ agarose gels. These conditions gave a reliable estimate of molecular sizes over a wide range $\left(3 \times 10^{6}\right.$ to $\left.80 \times 10^{6}\right)$ for which molecular weight and relative mobility were linearly related (Fig. $2 a$ ). Within this range, plasmid sizes determined by electrophoresis were within $10 \%$ of the values obtained by electron microscopy. For larger plasmids, up to $144 \times 10^{6}$, the linear relationship was no longer valid and the resolution of plasmid species was reduced. Preparations of plasmid DNA were subsequently run on 1.0 or $0.65 \%$ gels if the presence of plasmids within or near the chromosomal region was suspected. With $1 \%$ agarose, plasmid mobility was a linear function of molecular size from $3 \times 10^{6}$ to approximately $50 \times 10^{6}$ (Fig. $2 b$ ) and these conditions were not used for the determination of the size of large plasmids. Molecular weights in excess of $80 \times 10^{6}$ could be determined on $0.65 \%$ gels, but at this agarose concentration the mobilities of plasmids smaller than $10 \times 10^{6}$ were less than would be predicted from a linear relationship between molecular weight and relative mobility (Fig. $2 b$ ).

Recently an isolation procedure has been described which is specifically adapted to the preparation of large plasmids up to $300 \times 10^{6}$ (Hansen \& Olsen, 1978). In this technique, further steps were introduced to release plasmid DNA from the folded chromosome and to reduce contamination of plasmid DNA with chromosomal fragments. However, the alkaline denaturation involved lowered the yield of some plasmids and this may limit the application of the method in the analysis of wild strains.

\section{Detection of open circular and linear plasmid DNA}

It has been shown that open circular (OC) DNA generally migrates more slowly than the covalently closed circular form (Aaij \& Borst, 1972; Johnson \& Grossman, 1977). The relative mobilities of CCC and linear forms of plasmid DNA depend on gel concentration, 


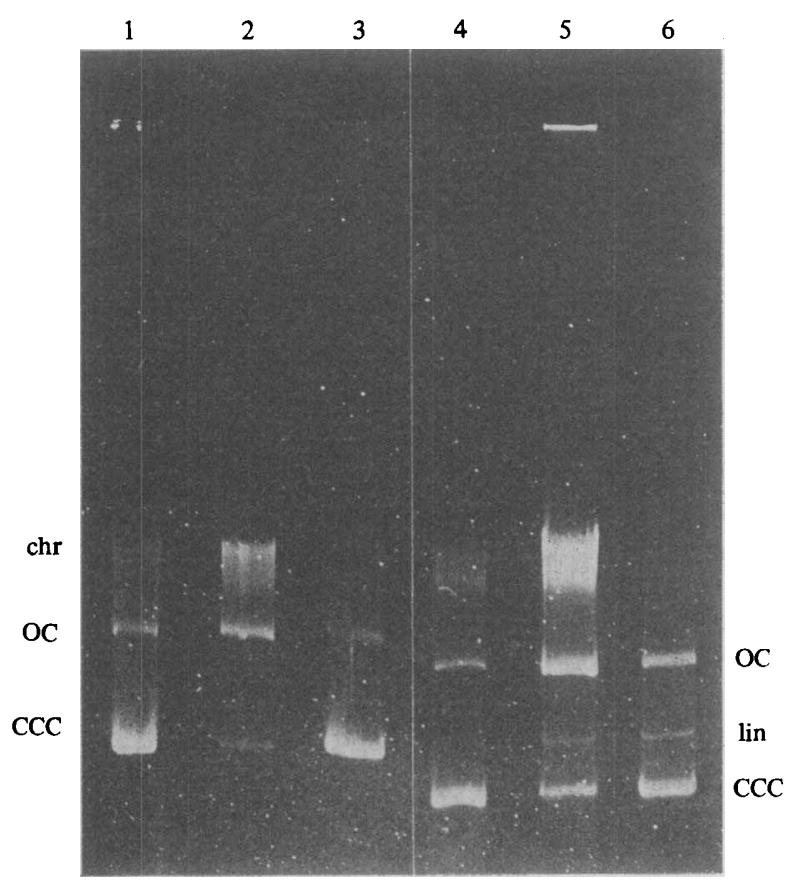

Fig. 3. Electrophoresis of covalently closed circular and open circular plasmid DNA. DNA of NTP16 $\left(5 \cdot 7 \times 10^{6}\right)$ and ColE1 $\left(4 \cdot 7 \times 10^{6}\right)$ was purified from plasmid-carrying lines of $E$. coli $\mathrm{K} 12$ by centrifugation of polyethylene glycol-precipitated cleared lysates in caesium chloride gradients containing ethidium bromide (Humphreys et al., 1975). Gradient fractions containing CCC or OC plasmid DNA molecules were dialysed against $0.01 \mathrm{M}$-Tris/ $\mathrm{HCl} \mathrm{pH} 8.0$ containing $1 \mathrm{~mm}$-EDTA. Samples were subjected to electrophoresis on $0.75 \%$ agarose for $3.5 \mathrm{~h}$ at room temperature; partially purified plasmid DNA preparations were run on the same gel. Tracks 1 to 3 show NTP16: 1, partially purified DNA; 2, OC DNA; 3, CCC DNA. Tracks 4 to 6 show ColE1 : 4, partially purified DNA; 5, OC DNA; 6, CCC DNA. Abbreviations: lin, linear plasmid DNA; chr, chromosomal DNA fragments.

electric field strength and DNA size (Johnson \& Grossman, 1977). During electrophoresis of freshly made DNA preparations from strains which carried a single plasmid of less than $10 \times 10^{6}$ in size, we frequently observed a slow-moving band in addition to the predominant fast-moving species which was presumably CCC plasmid DNA. Analysis of the plasmids in wild strains of $E$. coli and $S$. typhimurium also showed many bands moving ahead of the chromosomal DNA region. In this situation, it was important to determine the number of independent plasmids, and whether certain plasmids were present in the OC or linear configurations, as well as the CCC form. We therefore investigated the migration of different molecular forms of some standard plasmids under the conditions most commonly used for examination of wild strains.

Plasmid DNA of ColE1 (mol. wt $4.7 \times 10^{6}$ ) and NTP16 $\left(5 \cdot 7 \times 10^{6}\right)$ was purified on caesium chloride-ethidium bromide density gradients and samples containing CCC or OC plasmid molecules were subjected to electrophoresis. Preparations of CCC DNA (Fig. 3, tracks 3 and 6) showed a bright band, which corresponded to the faster moving band in tracks 1 and 4 which contained partially purified preparations of ColE1 or NTP16. Samples of OC DNA (tracks 2 and 5) contained predominantly molecules which migrated at the same position as the slower band in tracks 1 and 4 . In the ColE1 preparations (tracks 5 and 6), the faint band between $\mathrm{OC}$ and CCC forms contained linear plasmid molecules (see below). Thus, the $\mathrm{OC}$ form of plasmids within the size range $4 \times 10^{6}$ to $6 \times 10^{6}$ migrated ahead of chromosomal DNA fragments during electrophoresis of partially purified 


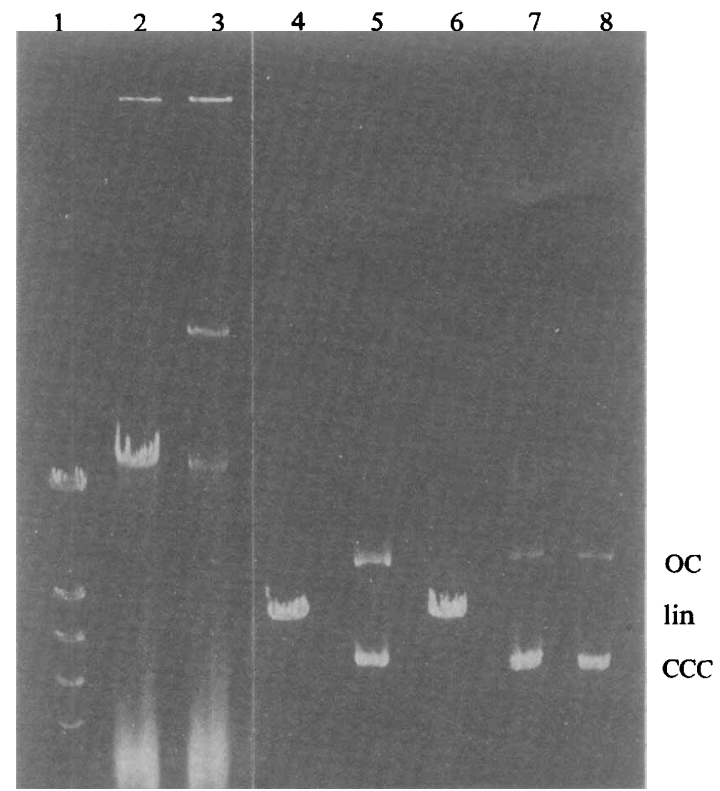

Fig. 4. Mobility of linear plasmid DNA on $0.75 \%$ agarose. Both ColE1 $\left(4 \cdot 7 \times 10^{6}\right)$ and RP1 $\left(37 \cdot 8 \times 10^{6}\right)$ have a single site for cleavage by $E c o$ RI endonuclease (Lovett et al., 1974; Jacob \& Grinter, 1975). Preparations of pure or partially purified DNA of these plasmids were dialysed against $0.01 \mathrm{M}$-Tris/ $\mathrm{HCl}$ pH 8.0 containing 1 mM-EDTA. Samples were digested with EcoRI (Miles Laboratories) by the method of Greene et al. (1974). Enzyme-treated DNA was subjected to electrophoresis on $0.75 \%$ agarose together with samples of the undigested plasmid preparations. Tracks: 1, Control - phage $\lambda$ DNA treated with $E c o R I ; 2$, partially purified RP1 plus EcoRI; 3, partially purified RP1, untreated; 4, pure ColE1 plus EcoRI; 5, untreated pure ColE1; 6, partially purified ColE1 plus EcoRI; 7 and 8, partially purified ColE1, untreated. Abbreviation: lin, linear plasmid DNA.

preparations under our conditions. In this position, the band could correspond to the CCC form of a plasmid with a molecular weight of $8 \times 10^{6}$ to $11 \times 10^{6}$. Since plasmids of $4 \times 10^{6}$ to $6 \times 10^{6}$ are common in wild strains (Smith et al., 1974; Crosa et al., 1977; see below) the presence of OC plasmid DNA is likely to complicate the interpretation of results.

In vitro techniques for the conversion of $\mathrm{CCC}$ to $\mathrm{OC}$ molecules, such as treatment with pronase, sodium dodecyl sulphate (SDS) or DNAase, have limited application to DNA preparations containing several plasmids. Electrophoresis in the presence of different concentrations of ethidium bromide has been proposed as a method for differentiation of CCC, linear and OC DNA (Johnson \& Grossman, 1977). As the ethidium bromide level is increased, the relative migration of the DNA configuration changes. This effect depends on the molecular size of the plasmid studied, so that the technique would be difficult to apply to wild strains. The most useful approach we found in the identification of plasmids present in more than one form in wild strains was to correlate the loss of properties, such as drug resistance or phage restriction, with the disappearance of more than one of the observed bands.

In contrast to our observations on small plasmids, OC molecules were not usually detected during electrophoresis of plasmids larger than $20 \times 10^{6}$, even after prolonged storage, repeated freezing and thawing of the preparations or treatment with SDS or pronase. Some plasmids, especially I-like $R$ factors within the size range $50 \times 10^{6}$ to $60 \times 10^{6}$, gave a low yield of CCC DNA. The DNA of these plasmids readily undergoes conversion from the CCC to the OC form (Clewell \& Helinski, 1969; Humphreys et al., 1972). These large OC molecules 


\section{Gel electrophoresis of plasmid DNA}

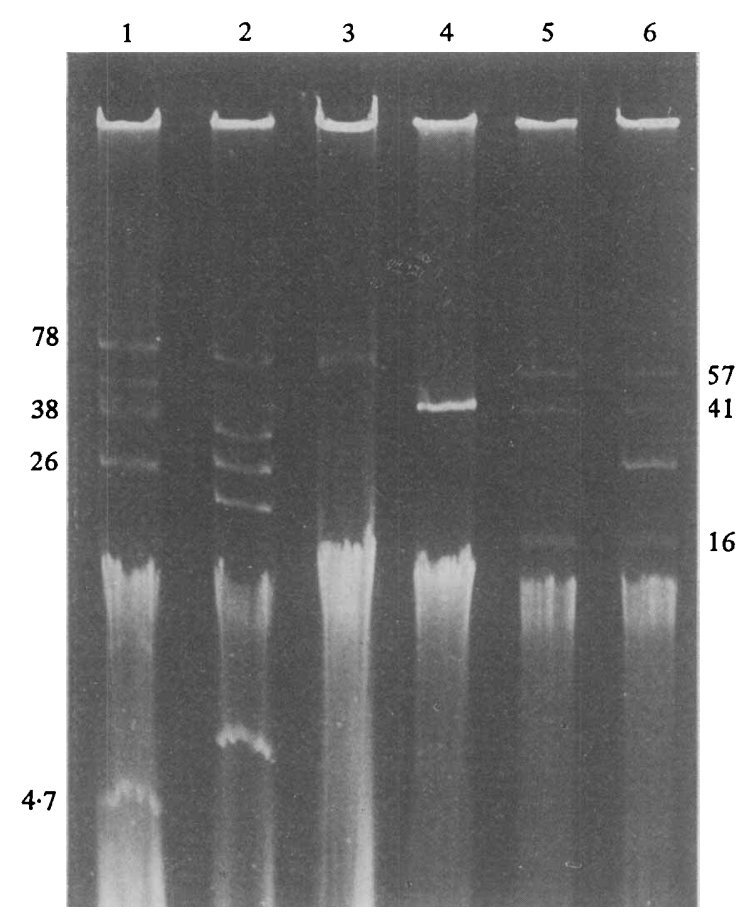

Fig. 5. Dissociation of plasmid DNA in S. typhimurium. DNA of the plasmid R1-19K- was partially purified from strains of $E$. coli $\mathrm{K} 12$ and $S$. typhimurium 36 . Samples of the preparation from each host were subjected to electrophoresis on $0.85 \%$ agarose for $4 \mathrm{~h}$ at room temperature. Tracks: 1 , standard plasmids of molecular weights $\left(\right.$ all $\left.\times 10^{6}\right) 4 \cdot 7,25 \cdot 9,37 \cdot 8,48 \cdot 0,77 \cdot 6 ; 2$, standard plasmids of molecular weights (all $\times 10^{6}$ ) $5 \cdot 7,20 \cdot 2,25 \cdot 9,31 \cdot 7,64 \cdot 0 ; 3, \mathrm{R} 1-19 \mathrm{~K}-$ in $E$. coli $\mathrm{K} 12 ; 4$, transfer factor isolated in $S$. typhimurium after loss of $\mathrm{R}^{1-19 \mathrm{~K}^{-}}$resistance markers; 5 and $6, \mathrm{R}^{-19 \mathrm{~K}^{-}}$in $S$. typhimurium - track 6 also contains a reference plasmid of molecular weight $25.9 \times 10^{6}$.

may not easily enter $0.75 \%$ agarose, resulting in an area of bright fluorescence which was often observed at the origin of the gel.

The position on $0.75 \%$ agarose of linear plasmid DNA relative to the $\mathrm{CCC}$ and OC form depended on the molecular size of the plasmid and is illustrated in Fig. 4 for ColE1 $(4 \cdot 7 \times$ $\left.10^{6}\right)$ and RP1 $\left(37.8 \times 10^{6}\right)$. Linear ColE1 molecules (tracks 4 and 6$)$ banded between CCC and OC plasmid DNA (tracks 5, 7 and 8), an observation similar to that of Johnson \& Grossman (1977) for molecules up to $11 \times 10^{6}$ in size. However, the linear form of RP1 (track 2) banded ahead of CCC DNA (track 3), in the same position on the gel as chromosomal DNA fragments.

\section{Electrophoresis of plasmid DNA isolated from different bacterial hosts}

The molecular nature of some resistance plasmids depends on the bacterial host which harbours them. F-like R factors, such as R1, R6 and R100, are isolated predominantly in a single CCC form from E. coli K12. In Proteus mirabilis, the DNA of these plasmids consists of three molecular species of different sizes. These correspond to the complete $\mathbf{R}$ factor, which dissociates to give the transfer factor region of the molecule and a region, termed the r-determinant, containing some or all of the drug resistance genes (for review, see Rownd et al., 1975). The plasmid R100, and other R factors coding for resistance to chloramphenicol, streptomycin and sulphonamides, also dissociate into three DNA species in $S$. typhimurium, but usually exist as a single molecular species in $E$. coli K12 (Sheehy et al., 1973; Humphreys et al., 1974; Humphreys, 1977).

Dissociation of plasmid DNA in $S$. typhimurium could be demonstrated by agarose gel 
Table 2. Properties of Salmonella typhimurium strains

\begin{tabular}{|c|c|c|c|c|c|c|}
\hline \multirow[b]{2}{*}{ Strain no. } & \multirow[b]{2}{*}{ Origin } & \multirow[b]{2}{*}{ Phage type } & \multirow[b]{2}{*}{$\begin{array}{l}\text { Resistance } \\
\text { type }\end{array}$} & \multicolumn{3}{|c|}{ Resistance plasmids carried } \\
\hline & & & & $\begin{array}{c}F_{1} \text { me } \\
\text { auto- } \\
\text { transferring }\end{array}$ & $\begin{array}{l}\mathrm{F}_{1} \text { me non- } \\
\text { auto- } \\
\text { transferring }\end{array}$ & $\begin{array}{l}\text { Other non- } \\
\text { auto- } \\
\text { transferring }\end{array}$ \\
\hline $14 \mathrm{M} 6407$ & Britain, 1974* & 208 & ACKSSuT & - & ACSSuT & $\mathrm{A}, \mathrm{SSu}$ \\
\hline $15 \mathrm{M} 1708$ & Iran, 1975 & 208 & ACKSSuT & - & ACSSuT & \\
\hline $15 \mathrm{M} 3557$ & Iran, 1975 & 208 & ACKSSuT & ACKSSuT & - & $\mathrm{AK}, \mathrm{SSu}$ \\
\hline 14M398 & Israel, 1974 & 208 & ACKSSUT & - & ACSSuT & $\mathrm{AK}, \mathrm{SSu}$ \\
\hline 16M5937 & Turkey, 1976 & Untypable $\dagger$ & ACKSSuT & - & ACSSuT & $\mathrm{AK}, \mathrm{SSu}$ \\
\hline
\end{tabular}

See Table 1 for definitions of drug resistance symbols.

* This strain was isolated from a patient who was infected in Iran (Anderson et al., 1977).

$\dagger$ The untypable strain carries a small-plaque temperate phage that converts type 208 into the untypable strain (Anderson et al., 1977).

Table 3. Plasmids present in wild Salmonella typhimurium strains

\begin{tabular}{|c|c|c|c|c|c|c|}
\hline \multirow{2}{*}{$\begin{array}{l}\text { Original } \\
S . \begin{array}{l}\text { typhimurium } \\
\text { strain }\end{array}\end{array}$} & \multicolumn{6}{|c|}{$10^{-6} \times$ Molecular weight of plasmid } \\
\hline & $\mathrm{F}_{\mathrm{I}} \mathrm{me}$ & A & AK & SSu & & \\
\hline $\begin{array}{l}\text { 14M6407 } \\
\text { Britain }\end{array}$ & 83 & $4 \cdot 3$ & - & $5 \cdot 7$ & - & - \\
\hline $\begin{array}{l}15 \mathrm{M} 1708 \\
\text { Iran }\end{array}$ & 90 & $4 \cdot 5$ & - & $5 \cdot 8$ & $3 \cdot 2$ & $3 \cdot 9$ \\
\hline $\begin{array}{l}15 \mathrm{M} 3557 \\
\text { Iran }\end{array}$ & 90 & - & $5 \cdot 7$ & $5 \cdot 7$ & $3 \cdot 2$ & - \\
\hline $\begin{array}{l}\text { 14M398 } \\
\text { Israel }\end{array}$ & 92 & - & 5.8 & $5 \cdot 8$ & - & $4 \cdot 0$ \\
\hline $\begin{array}{l}\text { 16M5937 } \\
\text { Turkey }\end{array}$ & 81 & - & $5 \cdot 9$ & $5 \cdot 8$ & $3 \cdot 0$ & $4 \cdot 2$ \\
\hline
\end{tabular}

See Table 1 for definitions of drug resistance symbols.

electrophoresis. Cultures of E. coli $\mathrm{K} 12$ or $S$. typhimurium phage type 36 carrying the $\mathrm{F}_{\mathrm{II}}$ plasmid R1-19K- (Table 1) were lysed with SDS; partially purified plasmid DNA was prepared and subjected to electrophoresis on a $0.85 \%$ agarose gel (Fig. 5). DNA of R1-19Kfrom $E$. coli $\mathrm{K} 12$ yielded a single plasmid band corresponding to a molecular weight of $57 \times 10^{6}$ (track 3 ). When the host strain was $S$. typhimurium, three plasmid DNA bands were visible, with molecular sizes of $57 \times 10^{6}, 41 \times 10^{6}$ and $16 \times 10^{6}$ (tracks 5 and 6 ; track 6 also contained a standard plasmid of molecular weight $\left.26 \times 10^{6}\right)$. The largest species present in $S$. typhimurium was the complete $\mathrm{R} 1-19 \mathrm{~K}-$ molecule, as observed in $E$. coli $\mathrm{K} 12$. The band of molecular weight $41 \times 10^{6}$ represented the transfer factor of $\mathrm{R} 1-19 \mathrm{~K}^{-}$; this was isolated as a separate plasmid in $S$. typhimurium after loss of the drug resistance markers of the $\mathrm{R}$ factor and migrated as a single band of $41 \times 10^{6}$ (track 4$)$. The resistance determinant region of R1-19K-, with a molecular weight of $16 \times 10^{6}$, was clearly resolved from chromosomal DNA fragments on $0.85 \%$ agarose (tracks 5 and 6 ). In the examination of the plasmid content of uncharacterized strains by gel electrophoresis, the ability of some plasmids to exist in multiple species of different sizes in some hosts may complicate interpretation of the results.

\section{Application of agarose gel electrophoresis to studies of drug-resistant salmonellae}

A large number of drug-resistant $S$. typhimurium strains of predominantly Middle Eastern origin have been studied recently in this laboratory (Threlfall et al., 1976; Anderson et al., 1977). The majority of cultures belong to phage type 208 and they probably represent a 


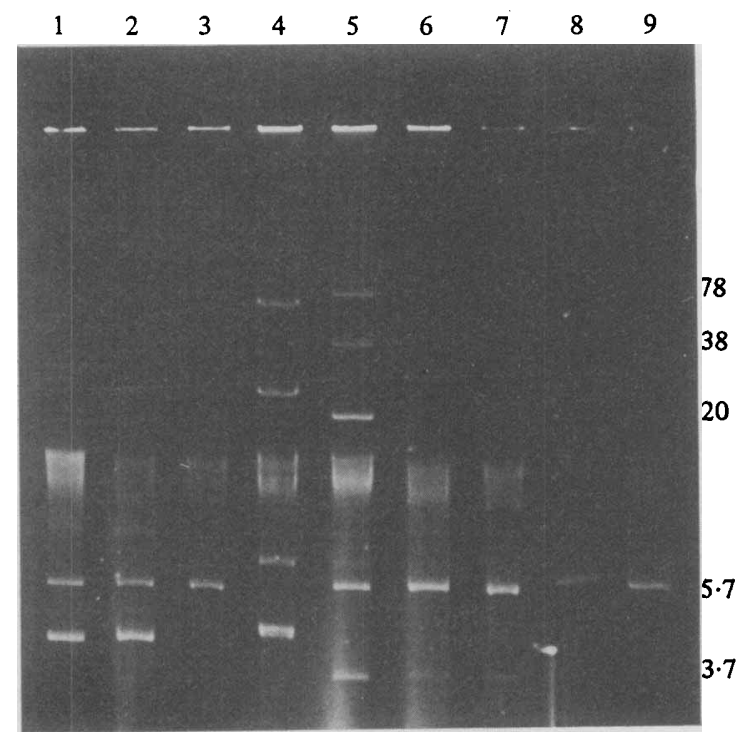

Fig. 6. Identification of plasmids in strains of S. typhimurium phage type 208 of Middle Eastern origin. Plasmid DNA was partially purified from the wild $S$. typhimurium strains and from plasmidcarrying $E$. coli $\mathrm{K} 12$ lines derived by transfer or transformation experiments. Samples were subjected to electrophoresis for $3.5 \mathrm{~h}$ on $0.75 \%$ agarose. Tracks 1 to 3 demonstrate small non-autotransferring plasmids in strain 14M6407: 1 , wild $S$. typhimurium; 2, E. coli K12 transconjugant containing A and SSu resistance plasmids - the faint band just ahead of the chromosomal DNA region corresponds to the open circular form of the A plasmid; 3, E. coli $\mathrm{K} 12$ transconjugant with SSu resistance plasmid only. Tracks 6 to 9 show small non-autotransferring plasmids in strain 14M398: 6, wild $S$. typhimurium; 7, E. coli $\mathrm{K} 12$ transconjugant resistant to ampicillin and kanamycin, and containing two plasmid species; $8, E$. coli $\mathrm{K} 12$ transformant with $\mathrm{SSu}$ plasmid only; 9, $E$. coli $\mathrm{K} 12$ transformant with AK plasmid only. DNA samples subjected to electrophoresis for demonstration of plasmids of less than $10 \times 10^{8}$ were too small for detection on the gel of the $\mathrm{F}_{\mathrm{I}} m e$ plasmids present in the strains. The molecular sizes of these plasmids were determined separately and are shown in Table 3. Preparations of standard plasmid DNAs were run in tracks 4 and 5; the molecular sizes of some of these reference plasmids are indicated on the figure.

clone of wide geographical distribution. Most strains carry a resistance plasmid belonging to the $\mathrm{F}_{\mathrm{I}} m e$ compatibility group which contains both autotransferring and non-autotransferring members. Molecular studies of $F_{I} m e$ plasmids demonstrated that they have molecular weights, determined by electron microscopy, of between $88 \times 10^{6}$ and $103 \times 10^{6}$ and show a high degree of DNA homology (Willshaw et al., 1978). In addition to the $F_{I} m e$ plasmid, these $S$. typhimurium strains carry A or AK and SSu non-autotransferring resistance plasmids.

The properties of five wild $S$. typhimurium strains from different countries are shown in Table 2. Partially purified plasmid DNA preparations from these strains were examined by gel electrophoresis. All five strains each carried only one large plasmid, which belonged to group $\mathrm{F}_{\mathrm{I}} m e$; the approximate molecular weights determined by electrophoresis on $0.75 \%$ agarose were between $81 \times 10^{6}$ and $92 \times 10^{6}$ (Table 3). In addition to $\mathrm{F}_{\mathrm{I}} m e$, at least two other plasmid DNA species were present in each of the strains; the sizes of these plasmids are shown in Table 3. Escherichia coli $\mathrm{K} 12$ derivatives were then examined to identify the DNA bands corresponding to the A, AK and SSu plasmids listed in Table 2.

The A, AK or SSu plasmids were mobilized into $E$. coli $\mathrm{K} 12$ with the I-like R factor $\mathrm{T}-\Delta$ in triparental crosses (Anderson, 1965). Plasmids present in recipient lines were examined by electrophoresis and compared with those detected in the five wild strains. With all five strains, $E$. coli $\mathrm{K} 12$ derivatives containing more than one species of small plasmid were obtained, and the identities of the different plasmids could not be determined with certainty. Partially purified plasmid DNA preparations from these strains were used 
to transform $E$. coli $\mathrm{K} 12 \mathrm{C} 600$ selecting for resistance to ampicillin, kanamycin or streptomycin. The transformants were analysed by electrophoresis, and usually only one plasmid which coded for drug resistance was present in each strain. Electrophoresis of preparations from two strains and $E$. coli K12 derivatives is shown in Fig. 6 and the plasmid content of all five $S$. typhimurium strains is summarized in Table 3. Four of the strains carried plasmids which code for no known function and were of at least two sizes. These 'cryptic' plasmids were, in some cases, mobilized into $E$. coli $\mathrm{K} 12$ together with the A, AK or SSu plasmids but were not usually present in transformants selected for drug resistance.

The similarities in plasmid content of the strains from the different countries support the view that a single clone of $S$. typhimurium phage type 208 has been widely distributed (Anderson et al., 1977). However, agarose gel electrophoresis has demonstrated differences in the number and size of the small plasmids present, and these changes have probably occurred during spread of the strain. These investigations emphasize the value of gel electrophoresis, in conjunction with genetic studies, for the identification of the plasmid content of enterobacteria. The techniques add to the range of methods now available for the epidemiological study of infection caused by these organisms.

\section{REFERENCES}

AAIJ, C. \& Borst, P. (1972). The gel electrophoresis of DNA. Biochimica et biophysica acta 269, 192200.

ANDERSON, E. S. (1965). A rapid screening test for transfer factors in drug-sensitive Salmonella typhimurium. Nature, London 208, 1016-1017.

Anderson, E. S., Threlfall, E. J., Carr, J. M., MCConnell, M. M. \& SMith, H. R. (1977). Clonal distribution of resistance plasmid-carrying Salmonella typhimurium, mainly in the Middle East. Journal of Hygiene 79, 425-448.

Clewell, D. B. \& Helinski, D. R. (1969). Supercoiled circular DNA-protein complex in Escherichia coli: purification and induced conversion to an open circular form. Proceedings of the National Academy of Sciences of the United States of America 62, 1159-1166.

Cosloy, S. D. \& OrSHI, M. (1973). The nature of the transformation process in Escherichia coli K12. Molecular and General Genetics 124, 1-10.

Crosa, J. H., Olarte, J., Mata, L. J., Luttropp, L. K. \& Peñaranda, M. E. (1977). Characterisation of an R-plasmid associated with ampicillin resistance in Shigella dysenteriae type 1 isolated from epidemics. Antimicrobial Agents and Chemotherapy 11, 553-558.

Datta, N., Hedges, R. W., Shaw, E. J., Sykes, R. B. \& Richmond, M. H. (1971). Properties of an $\mathbf{R}$ factor from Pseudomonas aeruginosa. Journal of Bacteriology 108, 1244-1249.

FREDERICQ, P. (1956). Recherches sur la fréquence des souches transductrices des propriétés colicinogènes. Comptes rendus des séances de la Société de biologie 150, 1036-1039.

Greene, P. J., Betlach, M. C., Boyer, H. W. \& Goodman, H. M. (1974). The EcoRI restriction endonuclease. Methods in Molecular Biology 7 , 87-111.

Grindley, N. D. F., Húmphreys, G. O. \& ANDERSON, E. S. (1973). Molecular studies of $\mathrm{R}$ factor compatibility groups. Journal of Bacteriology 115, 387-398.

Guerry, P., LeBlanc, D. J. \& Falkow, S. (1973).
General method for the isolation of plasmid deoxyribonucleic acid. Journal of Bacteriology 116, 1064-1066.

HANSEN, J. B. \& OlSEN, R. H. (1978). Isolation of large bacterial plasmids and characterization of the P2 incompatibility group plasmids pMG1 and pMG5. Journal of Bacteriology 135, 227-238.

Humphreys, G. O. (1977). The molecular nature of $\mathrm{R}$ factors in different bacterial hosts. In Topics in Infectious Diseases, vol. 2, pp. 277-293. Edited by J. Drews \& G. Högenauer. Wien: Springer-Verlag.

Humphreys, G. O., Grindley, N. D. F. \& AnderSON, E. S. (1972). DNA-protein complexes of $\Delta$-mediated transfer systems. Biochimica et biophysica acta 287, 355-360.

Humphreys, G. O., Willshaw, G. A. \& Anderson, E. S. (1974). Molecular nature of $R$ factors in different bacterial hosts. Proceedings of the Society for General Microbiology 1, 67.

Humphreys, G. O., Willshaw, G. A. \& Anderson, E. S. (1975). A simple method for the preparation of large quantities of pure plasmid DNA. Biochimica et biophysica acta 383, 457-463.

Humphreys, G. O., Weston, A., Brown, M. G. M. \& SAUNDERS, J. R. (1979). Plasmid transformation of Escherichia coli. In Proceedings of 4th European Meeting on Transformation and Transfection, pp. 254-279. Edited by S. W. Glover \& L.O. Butler. Oxford: Cotswold Press.

JACOB, A. E. \& GRINTER, N. J. (1975). Plasmid RP4 as a vector replicon in genetic engineering. Nature, London 255, 504-506.

Johnson, P. H. \& Grossman, L. I. (1977). Electrophoresis of DNA in agarose gels. Optimizing separations of conformational isomers of doubleand single-stranded DNAs. Biochemistry 16, 4217-4224.

LANG, D. (1970). Molecular weights of coliphages and coliphage DNA. III. Contour length and molecular weight of DNA from bacteriophages T4, T5 and T7, and from bovine papilloma virus. Journal of Molecular Biology 54, 557-565. 
LovetT, M. A., Guiney, D. G. \& HelinsKi, D. R. (1974). Relaxation complexes of plasmids ColE1 and ColE2: unique site of the nick in the open circular DNA of the relaxed complexes. Proceedings of the National Academy of Sciences of the United States of America 71, 3854-3857.

Meyers, J. A., Sanchez, D., Elwell, L. P. \& FALKow, S. (1976). Simple agarose gel electrophoretic method for the identification and characterization of plasmid deoxyribonucleic acid. Journal of Bacteriology 127, 1529-1537.

MeYNell, E. \& CoOKe, M. (1969). Repressor-minus and operator constitutive derepressed mutants of F-like $\mathbf{R}$ factors: their effect on chromosomal transfer by HfrC. Genetical Research 14, 309-313.

Rownd, R., Perlman, D. \& Goto, N. (1975). Structure and replication of $\mathbf{R}$ factor deoxyribonucleic acid in Proteus mirabilis. In Microbiology1974, pp. 76-94. Edited by D. Schlessinger. Washington, D.C.: American Society for Microbiology.

Sheehy, R. J., Perry, A., Allison, D. P. \& Curtiss III, R. (1973). Molecular nature of $R$ factor deoxyribonucleic acid isolated from Salmonella typhimurium minicells. Journal of Bacteriology 114, 1328-1335.

Smith, H. R., Humphreys, G. O., Grindley, N. D. F., Grindley, J. N. \& ANderson, E. S. (1973). Molecular studies of an $f^{+}$plasmid from strains of Salmonella typhimurium. Molecular and General Genetics 126, 143-151.

Smith, H. R., Hưmphreys, G. O. \& ANDERSon, E.S. (1974). Genetic and molecular characterisation of some non-transferring plasmids. Molecular and General Genetics 129, 229-242.

Smith, H. R., Hưmphreys, G. O., Willshaw, G. A. \& ANDERSON, E. S. (1976). Characterisation of plasmids coding for the restriction endonuclease EcoRI. Molecular and General Genetics 143, 319325.

Threlfall, E. J., Carr, J. M. \& Anderson, E. S. (1976). Compatibility relations of resistance plasmids in Salmonella typhimurium of Middle Eastern origin. Proceedings of the Society for General Microbiology 3, 88.

Willshaw, G. A., Smith, H. R., Anderson, E. S., Scotland, S. M. \& Gross, R. J. (1977). Application of agarose gel electrophoresis for the characterisation of plasmid DNA in drugresistant and enterotoxigenic enterobacteria. Proceedings of the Society for General Microbiology 4, 151-152.

Willshaw, G. A., Smith, H. R. \& Anderson, E. S. (1978). Molecular studies of $F_{I} m e$ resistance plasmids, particularly in epidemic Salmonella typhimurium. Molecular and General Genetics 159, 111-116. 